\title{
Scale and the construction of environmental imaginaries in local news
}

\author{
Mary Lawhon ${ }^{\mathrm{a}}$, Joseph Pierce ${ }^{\mathrm{a}}$ and Roy Bouwer ${ }^{\mathrm{b}}$ \\ ${ }^{a}$ Department of Geography, The Florida State University, Tallahassee, FL, USA; \\ ${ }^{\mathrm{b}}$ Department of Geography, Geoinformatics and Meteorology, University of Pretoria, Tshwane, South Africa
}

Abstract: Environmental imaginaries are shaped by a range of influences, including the media. While most analyses of the effects of environmental media coverage focus on national- and international-scale news outlets, local-scale outlets continue to be important: in some cases, they are the most commonly read news sources. We suggest that the role of local news in is particularly significant where local environmental imaginations diverge from global discourses. Mindful of the challenges of defining environmental media, we outline some of the potential implications of the distinctive properties of local environmental news coverage. We then explore the dissonance between global and a specific local environmental imaginary through a case study of community newspaper coverage in Boksburg, Gauteng, South Africa. Our analysis shows a strong focus on so-called "brown" issues, including concerns with pollution, water and electricity, in contrast to studies at other scales; when included, "green" issues are often presented idiosyncratically. In follow-up focus groups, local residents indicate that local environmental reporting resonates more with their own environmental imaginary than national or international scales of news sources. This disjuncture between local and global imaginaries has significant theoretical and political implications, warranting further investigation of local newspapers and environmental imaginaries.

Keywords: environmental media, environmental imaginary, scale, locality, South Africa

Environmental imaginaries shape and are shaped by a range of factors, including individual experiences, the built and biophysical environments, formal education, and cultural beliefs. Despite extensive examination of environments and environmental imaginaries (Huber and Currie, 2007; McGregor, 2004), there have been few geographical studies that consider the role of the media in shaping our understanding of the environment. Yet media accounts provide an important, accessible data set for examining environmental imaginaries, in that such accounts mediate between individuals' knowledge, public consensus, and political action (Cox, 2013; Hansen, 2010; Lester, 2010). While media studies have increasingly attended to environmental reporting, the geographical lens offers important additional insights into questions of environmental imaginaries, the construction of nature, scale and locality.

In this paper, we examine local environmental news reportage as an underutilized lens into local environmental imaginaries. Building on the literature in media studies, we recognize that the news is an incomplete proxy for local discourse, but it can provide important insights and perspectives. The vast majority of studies of environmental reporting focus on national or regional newspapers with relatively elite, nationally and internationally-oriented readerships (Hansen, 2010), leaving less explored the role of local news in contributing to environmental imaginaries, public discourse and policy agendas, despite their significance. We also draw on 
geographical insights which trouble the categories of nature and the environment, raising methodological questions about what counts as environmental reporting.

Here, we analyse environmental coverage in The Boksburg Advertiser, a free community weekly paper in Gauteng, and compare this with analyses examining international outlets. As is true in other analyses, we find a privileging of voices of authority. However, there are also key differences, including a significantly different profile of covered topics: while previous studies of national and world-regional news outlets have shown a dominance of global scale and 'green' issues (including a focus on biodiversity conservation and climate change, largely presented in apolitical framings), local reporting includes many more 'brown' issues (including environmental health and household services). Our local news analysis also showed explicit encouragement of reader action, notably different from international research findings. This work was followed by a series of focus groups in which residents reported that they both read more and felt more connected to local news, despite some concerns with the quality of local reporting; especially for lower-income readers. We posit that this picture has significant theoretical and political implications: if local environmental imaginaries are distinctive and scales of imagination are class-stratified, differences between local and national-scale environmental reporting are likely to have significant effects on (for example) public reactions to environmental policy and willingness to support 'green' policy interventions. We thus argue for greater scholarly attention to the divergence between local and international environmental imaginaries, including attention to how they are represented through media accounts.

\section{Scalar geographies and environmental imaginaries}

Social and political geographers have sought to explain the relationships between the environment, place, geographical imaginaries and their impact on actors' behaviour. Imaginaries are experiential: as a result, they are always examined as research objects via discourse (especially public or political discourse) about them. For example, Peet and Watts use the related term 'regional discursive formations' to describe "certain modes of thought, logics, themes, styles of expression, and typical metaphors" that tend to "run through the discursive history of a region, appearing in a variety of forms... A regional discursive formation also disallows certain themes, is marked by absences, repressions, marginalised statements, allowing some things to be mentioned only in highly prescribed, 'discrete', and disguised ways." For Peet and Watts, these regional discursive formations "originate in, and display the effects of, certain physical, politicaleconomic, and institutional settings" (Peet and Watts, 1996, 16). Such formations, according to Mels (2009, p. 387), “articulate and develop a society's wider 'environmental imaginary' in which discourses of nature are a principal element." We see environmental place imaginaries as emergent from experience at a variety of scales, but focus here particularly on urban/local imaginaries and how they may be shaped by distinct and different communities of discourse: for example, local news.

Social and political geographers have explored various ways that the place imaginaries (sometimes, "place frames") of residents and advocates shape actors' behaviour, as well as policy outcomes, at multiple scales. A place imaginary is the result of individuals' and communities' efforts to understand what counts as part of a place and what does not: the combination of physical, social, and experiential elements which are claimed as related to a place, as well as those which are rejected as being 'somewhere else'. While place imaginaries are immaterial (that is, they are experienced internally by urban stakeholders), they have material 
implications and political impact (Elwood et al, 2014; Holifield and Schuelke, 2015).

Imaginaries thus have important social and political dimensions and can be used to enrol others toward political ends ${ }^{1}$ (Pierce et al, 2011). In a local environmental context, for example, some residents' place imaginaries might be explicitly industrialist, and thus discount the importance of toxic discharges while privileging infrastructures which enable new industrial development; other residents might imagine the place as effectively post-industrial, thus demanding environmental remediation to enable jobs growth (Pierce and Martin, 2015).

At the urban scale, geographers have examined how differing imaginaries of the city shape people's willingness to invest in or rebuild neighbourhoods (Kitson and McHugh, 2014; McCauley and Murphy; 2013), eat or shop in those areas (Harris, 2010), or even move bodily through them (Pierce and Lawhon, 2015). Recent scholarship has also emphasized how individual or collective self-perception is intertwined with the (re)production of urban place imaginaries: for example, when tourists select destinations by matching themselves against the places they might visit (Akerlund and Sandberg, 2014) or permanently resettle (Rios and Watkins, 2015). Place imaginaries can be affectively positive or negative: one thread of recent research, for example, focuses on how fearful imaginations of the landscape shape both broad patterns of development and individual well-being (Lemanski, 2004; Roberts, 2010; Edensor, 2015; Shaw, 2015). These imaginaries are often politically unconsolidated in the sense that different groups imagine a place differently, using these distinctive frames as they attempt to motivate change (Pierce and Martin, 2015).

A number of scholars have emphasized the specific effects of environmental imaginaries at urban and other scales. Huber and Currie (2007) and Hagerman (2007) note the consolidating importance of environmentally responsible development in the shared public imaginary of the city of Portland, Oregon, USA. Escobar (2001) and Castree (2004) both highlight how subaltern communities can use local and particularist environmental discourses to 'make place' for themselves in the context of hegemonic neoliberal framings. Environmental discourses are one way - though by no means the only way - that normative claims about capitalism are resisted "from below". Conversely, Millington (2013) reflects on how environmental imaginaries are also mobilized in ways that displace less-advantaged urban communities (i.e., through gentrification or the capture of community resources for those with more social capital). Concerns about unsustainability and climate change have also motivated increased attention to "international" and even "global" environmental imaginaries. These imaginaries quilt together divergent communities in different places by situating them in the context of either global environmental catastrophe (Baeten, 2002; Kallis and March, 2014; Strauss, 2014; Braun, 2015) or global responsibility in the age of the Anthropocene (Lipset, 2014; Derickson and MacKinnon, 2015; Gandy, 2015). Importantly, Martinez-Alier (2003, 2014) has challenged the universalism of global discourses, proposing that we also consider the "environmentalism of the poor", though this has been critiqued for obscuring local differences (Lawhon, 2013).

While much of the literature on place imaginaries is built upon global North empirics, we argue that the concept of imaginaries helps highlight two important issues for our study. First, public discourse (including news reportage) iteratively represents and mediates place

\footnotetext{
${ }^{1}$ Pierce et al (2011) suggest that these political ends can be specific, such as resistance to a hospital facility expansion that is perceived as undermining neighbourhood character; or more spatially diffuse, such as seeing a particular mode of industrial and economic development as in keeping with place values, while other development strategies might be not in keeping with regional cultural character.
} 
imaginaries, even though imaginaries are ultimately experienced by individuals. Second, the geographies which people imagine are (re)produced, not given; thus, we focus on the ways in which local reportage contributes to particular imagined scales of attention to environment through patterns of coverage. Put another way, rather than focusing on the flow of news information (at whatever scale) — that is, rather than focusing on the empirical object of discourse per se-we use the geographic concept of place imaginaries to help focus on the constructs of experienced locality to which reportage at local scales might contribute distinctively.

\section{The geography of environmental news and its analysis}

News media have a complex relationship with public perception, both influencing and being influenced by science and scientific priorities, particular problem framings, policy, and public perception (Molotch and Lester, 1974; Gans, 2004). News media may not necessarily result in direct and measurable action from readers (Shanahan et al. 1997; Sampei and AogoyiUsui 2009), but nonetheless have importance in shaping what and how issues are thought about, creating indirect and difficult to measure impacts. Building on this scholarship, we adopt the position that environmental journalism represents news organizations' efforts to respond to their beliefs about the demands of their audience both for news about environmental "events" and contextualization of those events in the kind of knowledge systems that the audience values (Funkhouser, 1973; Herman and Chomsky, 1988). In this section, we review key themes in environmental news analysis most relevant to our consideration of local environmental imaginaries. We note that: i) environmental reporting differs internationally, and global South analyses in particular differ from global environmental imaginaries, and ii) research has primarily been undertaken at national and international scales ${ }^{2}$, and what studies of local scales have been done (of environmental and other topics) indicate difference.

The lack of understanding of local media is particularly problematic given the importance of local news. As Bessinger (2013, no page) notes for South Africa, "Almost 70\% of decision makers [read] their relevant local newspaper every week. In contrast most daily and weekly newspapers are seeing a decline in readership penetration. Since the last survey in 2010, daily and weekend readership has declined $12 \%$ across trended similar areas." We suggest that one of the reasons why community newspapers remain important is because place identities remain significant, and local papers are able to provide both content and framings that respond to and reinforce this place identity. These forces produce a particular kind of relationship between residents of a place and its local newspaper, and we suggest that they may well powerfully shape environmental imaginaries.

The vast majority of analyses of environmental media have focused on newspapers in the global North, and therefore key findings from this literature must be understood in this context. Studies from the global South have sought to compare their findings with these established trends, and found many similarities and some key differences. One commonality which mirrors that of journalism more generally is that environmental reporting tends to emphasise the voices of authority, including social and economic elites (Boykoff and Boykoff, 2007; Hansen, 2010; Lester, 2010). In environmental reporting, scientists and government officials are generally portrayed as experts while citizens rarely are given explicit voices. Where present, they are

\footnotetext{
${ }^{2}$ Such researchers have typically considered scale as a methodological point to identify rather than a lens of analysis: we recognize that scale is socially and relationally constructed, and therefore there are relationships between imaginaries and events at different scales. We consider the implications of this below.
} 
frequently framed as without agency, including portrayal as victims (ibid). A second trend is that there is greater emphasis on green than brown issues ${ }^{3}$ (Lawhon and Fincham, 2004; Guedes, 2000; Chapman et al., 1997 find this true in the UK, but not in India). Common environmental issues include wildlife and conservation and technological solutions to sustainability challenges; as Lewis (2000, p. 244) notes in a review of the term sustainable development in major U.S. newspapers, it "is presented almost exclusively within an economic growth paradigm that assumes that economic growth, technology, and northern expertise are the most effective way to achieve development." Such framings largely present the environment as something "out there" rather than directly relevant to a paper's readership.

Comparative studies have shown that the content of environmental journalism differs internationally, though fewer of these have analysed the discourse used in these papers. For example, a study of American and French media demonstrates that climate change is more prominent in the French media. The authors assert that this is because the French media tends to be more opinionated and institutionally motivated (Brossard et al., 2004). National economies and the associated environmental issues also shape content: a study of environmental reporting in Argentina, Chile, Mexico and the Philippines found that manufacturing and industrial sectors are the most common topics for Argentina, Mexico and Philippines, while in Chile roughly a third discuss mining and quarrying and another third are agricultural, forestry and fishing related (Dasgupta, et al., 2000). However, while the national economies informed reportage, the media is not simply led by what issues are most pressing; although electricity and water articles are rare they make up significant portions of environmental issues in all four of the countries (ibid).

In addition to the topics analysed, environmental news varies in how it represents particular issues. Chapman et al. (1997) find in their comparison of the UK and India that the process of knowing the environment differs between these contexts, and this shapes both environmental news and interpretations of it. For example, while many British readers have read about climate change science, many Indian farmers claim to have observed changing weather patterns. The formation of public opinion and perceptions therefore is affected by the media's representation of the environment as well as the local context and personal experiences of with a specific community of place (Hansen, 1991; Pierce et al., 2011). This means that the value attached to news articles is shaped by readers' understanding of those issues' relevance in local, emplaced context.

Environmental analyses have given some consideration to the scale at which environmental issues are framed. In Brazil, Guedes (2000) notes that $31 \%$ of environmental articles refer to international issues; Batta et al. (2013) found an even higher percentage-- $63 \%$-in their analysis of Nigerian media. Tagbo's (2010) review of climate change coverage in South Africa found $70 \%$ of articles without South African or African content. The implications of this are significant, although not always clearly outlined: there is likely a link between such externalizing framings and the construction of an environmental imaginary that places the environment as something "out there", happening at other scales and in other places. For example, in Japan, Amu and Agwu (2012) found that $23.8 \%$ of participants believe the

\footnotetext{
${ }^{3}$ The difference between green and brown agendas is rooted conflict between environmentalists and development advocates. In this context, 'brown' environmental issues relate "to public health and sanitation, the need for recreational space and the occupation of most spacing by human construction" in contrast with "green issues concerned with the preservation, conservation or recovery of the landscape where the human footprint is minimized or eliminated" (Freund, 2001, p. 718). McGranahan and Satterthwaite (2000) further specify that green issues are about reducing consumption while brown issues are about increasing access to services, a key consideration in South Africa.
} 
environment was the most serious issue in the world while only $2.5 \%$ believed it was the most serious issue in Japan. This sharp divide between issue affinity at different scales raises questions about how local communities engage with, and relate to, national and international media's representations of environmental issues. Further, this has particular significance in contexts where globalized representations of the environment do not accord with local environmental imaginaries (Chapman et al., 1997; Jones, 2012).

In reviewing this literature, we found an important conceptual and methodological challenge when seeking to draw generalizations across studies: few studies identified how authors defined what counts as an environmental issue. For example, brown issues such as the provision of water and sanitation may well have been present in the media examined in some of these studies, but not included in the samples. Drawing on geographical studies of the construction of nature and the environment (Castree and Braun, 2001), we note that different definitions and categorizations shape research findings; we reflect further on the implications of this in our own study below.

Analyses of environmental reporting have typically focused on news outlets which have a national or regional scale (Hansen, 2010), a point true for media studies more generally (Soloski, 1989). What and how issues are presented in local news coverage, especially in smaller urban markets, has been far less thoroughly examined. Local media, and local newspapers specifically, fill a niche within the journalistic field (Benson, 2004) and "may involve themes, frames, and actors that are distinctly different from those prominent at the national level" (Priest and Ten Eyck, 2004, p. 188). Hansen (2010), in a review of environmental media, found that "local/regional" environmental media studies tend to include more lay voices and more coverage of local issues, although there is a decrease in critical analysis and willingness to critique local industries. For example, Taylor (2000) examines a community newspaper and finds it supportive of industry against Greenpeace and a local environmental organization. Local papers, importantly, are typically under-resourced; when a news organization develops sufficient resources to produce more widely relevant news, it tends to shift in audience and editorial attention, becoming relevant to both a more spatially diffuse and demographically narrower (typically more affluent) audience. This problem is particularly true in the South African context where resource constraints are felt widely and environmental journalists are rare (Jones, 2012).

The studies described by Hansen (2010) in his overview of scalar differences include research on countries and many are at the urban scale and focused on a specific issue. For example, while Crawley (2007) uses the term "community", the newspapers examined have distribution throughout the city of Oakland, California as well as the largest by circulation newspaper in the state of Missouri (both with populations in the millions). One study by geographers (Wakefield and Elliot, 2003) does look at small scale local media, but their work looks at its effectiveness in alerts, a rather different focus from our wider project here. Further, none of these studies were undertaken in the global South (although see Lawhon and Makina, In press, for a recent analysis of The Sowetan, another South African newspaper). We point to these examples not to criticise terminology, but in order to highlight the conflation of studies at different scales and to suggest that scale remains largely unexamined as a factor influencing environmental content; small-scale newspapers remain largely outside of our understanding of environmental reporting internationally.

What are the broader implications of these two findings from the literature, that environmental reporting differs internationally and at different scales? Given the relationship between media and public opinion outlined above, and supported by the wider literature 
(Martinez-Alier 2003; Lawhon 2013), we may thus assume that environmental imaginaries too vary across these different spaces and scales. The implications of this are significant both theoretically and politically. In terms of theory, there is an important gap in our understanding of the varieties of environmentalism. The international discourses dominating the academic literature may well not be dominant in most people's everyday lives, leaving unexplored a plethora of conceptual alternatives. Normatively, this might provide some insight into why the environmental movement often fails to resonate across places and scales. Understanding local framings as environmental, albeit differently so, may well help with coalition building across difference. While the above literature review is indicative, further work is needed to better understand the different, distinctive local environmental imaginaries in different places, and the ways in which local media contribute to these.

\section{Local environmental reporting in Boksburg, South Africa}

Consumption of newspapers has changed, particularly as readers increasingly use online sources, but newspapers continue to have an important role in both national-scale and local news production. In South Africa, most metropolitan areas have many national and regional newspapers that compete for market share which, as in other contexts, compete by differentiated editorial tone, topical coverage, physical format, and price. Free so-called "community" papers have highly geographically circumscribed distributions which are often read by residents; such papers have garnered much less attention in South Africa and internationally. We therefore selected one of these papers for our analysis: The Boksburg Advertiser, the most commonly read newspaper in the area (65\% of the population) distributed to 44000 households on a weekly basis (Roots Survey, 2013).

Our choice of The Advertiser is based on the desire to examine a locale that is underrepresented in urban and environmental research and retains an historical place identity, as well as because of Author C's familiarity with the local context. The former Boksburg Municipality is no longer a distinct governmental entity, having merged with several other smaller governmental units in 2000 to become the Ekurhuleni Metropolitan Municipality, part of the wider Johannesburg-Pretoria city region (Ekurhuleni Metropolitan Municipality, 2004; Gervais-Lambony, 2010). The reconfiguration of local political representation in post-apartheid South Africa involved a general scaling-up, in which smaller historically white and urban governance units were combined with surrounding areas which were typically majority black or coloured. Practically, these new governmental units both diluted local white political power and provided a mechanism for redistribution of wealth via local tax policy (Parnell and Pieterse, 2002). Despite this political reconfiguration, the local newspaper which served the former Boksburg retained its original toponym, a point which is significant but not unusual in the South African context: it is not uncommon for the residents of former city governmental areas to retain ties to historical place identities. The newspaper's formal circulation area is roughly analogous to the former municipality's limits, with the exclusion of both industrial areas and informal settlements (see Figure 1, which includes the circulation map and Villa Liza). 


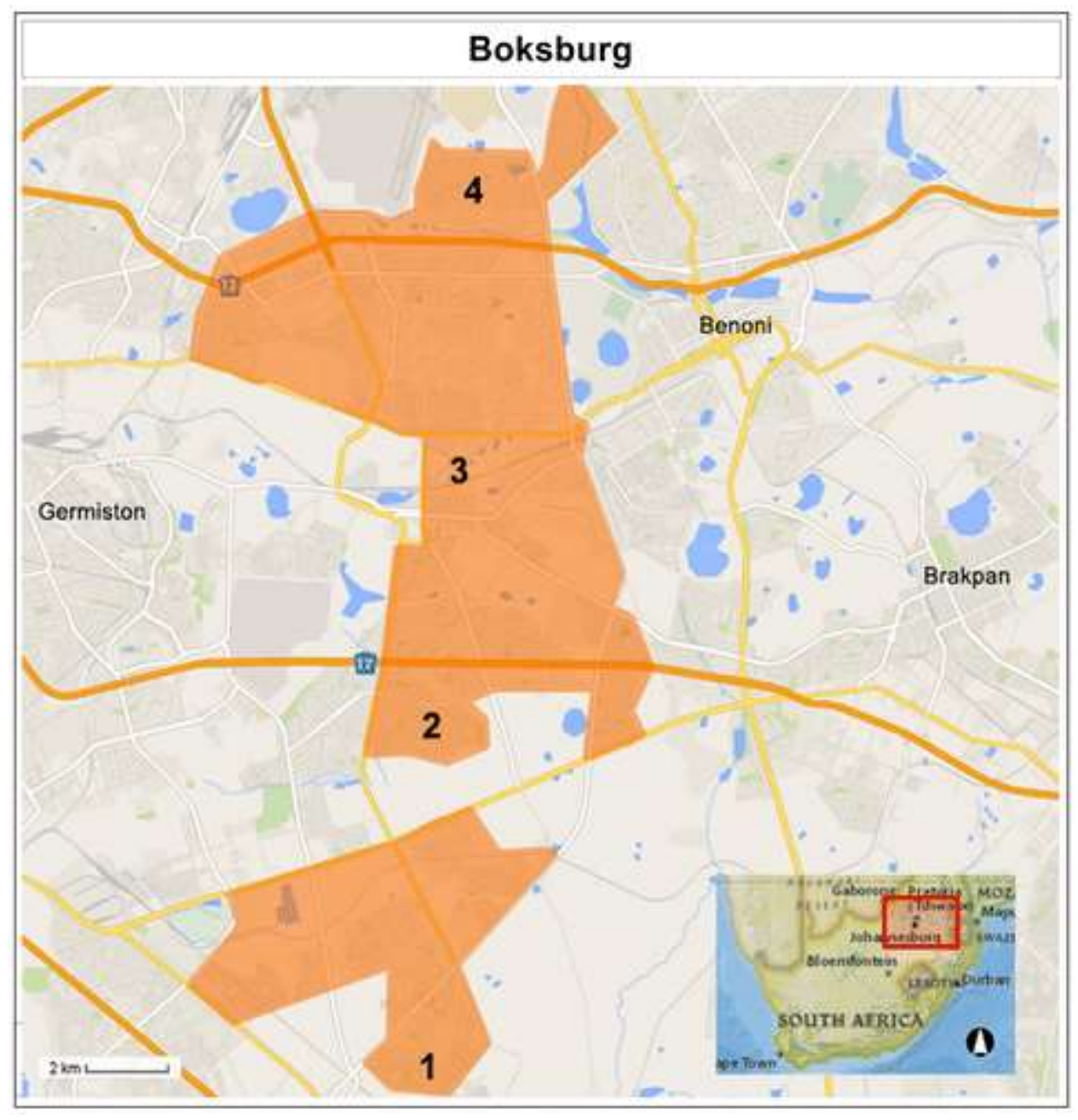

FIGURE 1. Circulation of The Boksburg Advertiser (plus Villa Liza), and focus groups sites.

Boksburg has a distinct place identity with which residents associate. Formed during the apartheid era, it was a working- and middle-class, majority-white city with a reasonably stable residential population who understood the trade-offs between jobs and environment that come with proximity to primary production facilities such as those in the mining industry. The wider East Rand region was the manufacturing core of South Africa, and has a strong history of organized labour (Barchiesi, 2010) combined with a reputation for social conservativism in contrast to the more liberal Johannesburg. Since 1994, even as the area became both more racially diverse and less of an economic growth region, elements of this place identity and sense of working-class development orientation have, anecdotally at least, remained: Todes et al. (2010), for example, note that "there is a common perception among planners and politicians that the [Ekhurhuleni] municipality lacks a specific identity as an entity, as the nine towns [and, by implication, the city of Boksburg] still have stronger identities than municipality as a whole." The Roots Survey of 2013 (a marketing survey and the most recent publicly available study on the demographics of Boksburg) states that there are 38863 households: 57\% of residents are white while $30 \%$ are black with coloured and Indian residents each comprising $7 \%$ of the 
population. Nearly half claim English as the home language. The unemployment rate is much lower than in the rest of municipality at $8 \%$.

Our observations from regular consumption of South African news suggest that the municipality does not feature prominently in national or provincial news. Nonetheless, according to Ekurhuleni's executive mayor Duma Nkosi, residents face constant challenges to well-being and livelihoods particularly because of the environmental impacts of heavy industry in the municipality (Ekurhuleni Metropolitan Municipality, 2004). Land use in Boksburg is largely urban commercial and mining (which has contributed to poor water quality), however there are some areas which are classified as important for conservation; the Bleskokspruit Wetlands is recognized by Ramsar as an internationally significant wetland and is home to threatened plant and animal species and untransformed portions of grasslands. Although there are not many cases described as resulting from environmental health challenges, there are regular concerns with diarrhoea and asthma in children.

\section{Methodology}

We adopted two different strategies for collecting news articles as a way of providing some insight into the question of what counts as an environmental issue, and as a response to technological shifts at the newspaper (The Advertiser was made available online in 2014). For Sample 1 (S1), we hand selected articles from hard copies from Jan-Dec 2013, using one randomly selected edition from each month, and applying a wide definition of environmental coverage. This resulted in twenty news articles; to match Sample 2 (S2), we did not collect letters to the editor or advertisements. For S2, we used a keyword search for the term "environment" in the newspaper's online database, and sorted these by relevance (only news articles were returned). We selected the top twenty articles to match $\mathrm{S} 1$. At the time of our search, the database covered Jan 2014-July 2015. Within this latter group, we excluded articles which used the term as a synonym for 'context', as in phrases such as 'the business environment" or "a safe environment".

We then undertook a content analysis building on that of Lawhon and Fincham (2006) and Guedes (2000) using the following categories: Green issues (Nature), Brown issues (Pollution/rubbish, Transport, Water and Electricity provision), Climate and weather, and General Comments. Interestingly, the General Comments label was not used in any of the literature we reviewed, but a pilot study suggested the need to explicitly label this theme as often the environment was referred to in the abstract, particularly in reference to green awards, green lifestyles, or by celebrities expressing concern for the environment. We suggest this may be indicative of a wider trend in which environmentalism rather than the environment becomes the focal point, rather than a specific feature of local news. On a second iteration, we reviewed articles within each theme for notable patterns, particularly looking at whether they mirrored findings in the on environmental media literature discussed above.

Our two samples did differ slightly, confirming the need to consider the definition of the environment explicitly in environmental media analysis. The hard copy search collected a wider range of relevant articles than searching for the term environment. Specifically, S1 included articles about domestic water, energy access and weather related incidents that were not present in S2. A search of the database indicates these issues were covered, but the search criteria excluded them from the sample. This variance calls attention to the difficulty of categorizing environmental issues, raises methodological concerns in an increasingly digitalized media 
context, and questions regarding whether the criteria should emerge from the texts (to include only those that use the term environment) or from scholarly practice (to include articles that fit a geographical definition, or that parallel other media studies). Despite these small but notable differences, below we merge the two samples to discuss the overall findings from the forty articles, noting differences where these are salient.

Additionally, five focus groups were held with 33 residents (see Figure 2 for more detail) to begin developing insight into resident reception of and responses to news reporting. We recognize that these are illustrative not representative, and that focus groups provide insight into residents perceptions, not objective facts. The focus groups were arranged through contact with prominent members in each area; a range of individuals were contacted, and focus groups set up with the first willing respondents from different socio-economic areas. Socio-economic areas were categorized based on the dominant housing type in the neighbourhood, and in consultation with key informant residents. Villa Liza, (1 on Fig. 1), was an Indian township during the apartheid era, but is now is home to primarily black African residents. It consists of low-cost housing, government-subsidized "RDP" housing, and informal housing. Sunward Park, (2 on Fig. 1), has predominantly white residents and is associated with high income and large property values. Boksburg Central ( 3 on Fig. 1) is the previous central business district and now consists of a mix of residents and faces significant urban decay. Two focus groups were done at this location because the area draws residents from the local area as well as from surrounding areas in Boksburg. Impala park (4 on Fig. 1), is a predominantly white middle class area.

\begin{tabular}{|c|c|c|c|c|c|}
\hline Suburb & $\begin{array}{l}\text { Suburb } \\
\text { Average } \\
\text { Income }\end{array}$ & Race & Home language & Gender & Age \\
\hline Vila Lisa & Low income & $\begin{array}{l}\text { Black } \\
\text { residents }\end{array}$ & Zulu home language & $6 \mathrm{~W} ; 4 \mathrm{M}$ & $\begin{array}{l}2: 50+; 8: \\
18-35\end{array}$ \\
\hline Sunward Park & High income & $\begin{array}{l}\text { White } \\
\text { residents }\end{array}$ & $\begin{array}{l}\text { All white, Afrikaans } \\
\text { home language }\end{array}$ & $2 \mathrm{M} ; 2 \mathrm{~W}$ & $50+$ \\
\hline Boksburg Central A & $\begin{array}{l}\text { Low and } \\
\text { middle } \\
\text { income }\end{array}$ & $\begin{array}{l}4 \text { white } \\
\text { resident, } 1 \\
\text { black resident. } \\
1 \text { coloured } \\
\text { resident: }\end{array}$ & $\begin{array}{l}\text { Multiple home } \\
\text { languages }\end{array}$ & $6 \mathrm{M}$ & $\begin{array}{l}2: 50+, 4: 35- \\
50\end{array}$ \\
\hline Boksburg Central B & $\begin{array}{l}\text { Low and } \\
\text { middle } \\
\text { income }\end{array}$ & $\begin{array}{l}7 \text { white and } 1 \\
\text { coloured; }\end{array}$ & $\begin{array}{l}\text { Multiple home } \\
\text { languages }\end{array}$ & $8 W$ & $\begin{array}{l}7: 35-50 ; 1: \\
18-35:\end{array}$ \\
\hline Impala Park & $\begin{array}{l}\text { Middle and } \\
\text { upper } \\
\text { income }\end{array}$ & $\begin{array}{l}\text { All white } \\
\text { residents }\end{array}$ & $\begin{array}{l}\text { English home } \\
\text { language }\end{array}$ & $4 \mathrm{~W} ; 1 \mathrm{M}$ & $\begin{array}{l}\text { I: } 18-35 ; 3 \\
35-50 ; 1: 50+\end{array}$ \\
\hline
\end{tabular}

FIGURE 2. Summary description of focus group participants. 
We also attempted interviews with reporters from The Advertiser, but were unable to obtain a positive response $\mathrm{H}^{4}$. Given the focus of this paper on environmental imaginaries rather than environmental journalism, we find this only a minor shortcoming; in what follows, we focus on explicating what the articles said, how they said it, and readers' perceptions.

\section{Local environmental news reportage in the Boksburg Advertiser}

Our analysis suggests that local media differ from coverage by national and international news outlets in terms of what and how environmental issues are covered. We found more than twice as many articles covering brown than green issues: Pollution/Rubbish (9), Transport (3), Water and Electricity Provision (8) totalled half of the sample (20); Nature was only the theme in seven articles. The remainder were unable to be classified in this way, and included Climate Change/Weather (3), and General Commentaries (11). (See Figure 3). Articles, however, often did not adopt recognizable international environmental discourses, raising challenges for our classification. For example, after much discussion, we labelled an article about a death at Boksburg Lake (No Author, 2013, Jan 25) as "Nature", although certainly this is an unconventional frame. With this in mind, we present a summary of our findings, including key examples of each theme.

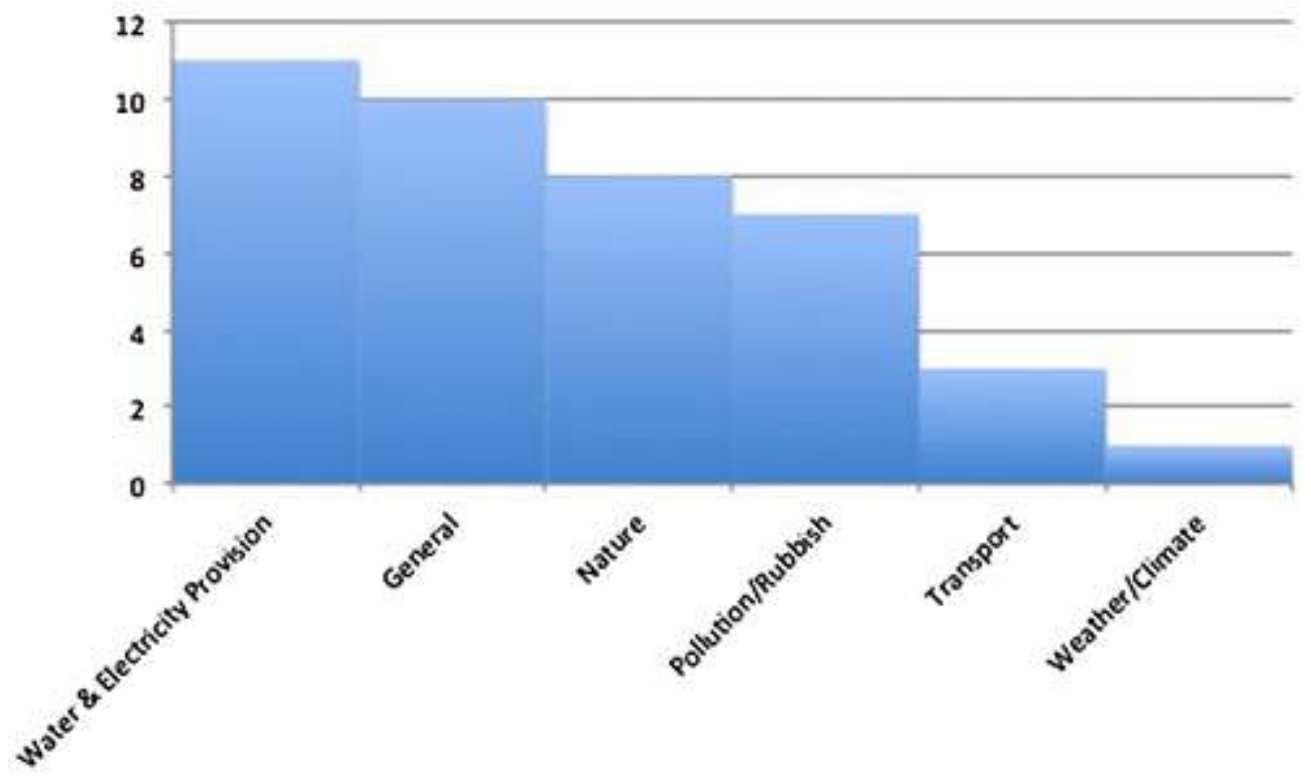

FIGURE 3. Environmental themes in The Boksburg Advertiser.

Articles in the category Pollution/Rubbish presented the topic in a way that largely conforms to international environmental discourses: pollution and trash are negative, and need to be managed to keep them in control and out of sight. In contrast to international and national

\footnotetext{
${ }^{4}$ In our initial approach, we were able to schedule a meeting. Upon providing more information specifying our interest in environmental reporting, however, the offer to meet with us was withdrawn. We note this as an indication of the sensitivity of environmental reporting at the newspaper; while we cannot know for certain why our focus on envitonmental reporting led to reduced access, we speculate that the staff may not have wanted to discuss their limited staff capacity or overall environmental focus.
} 
media coverage, however, these articles often focused on individual action. For example, an article entitled "Don't throw trash in drains- urges Metro" (No Author, 2013, March 1) is a straightforward plea from the local government. "Why you should recycle" (No Author, 2015, 1 June) is equally instructive. Articles in this theme sometimes also mentioned aspects of 'Nature': four articles focused on pollution in the water, and one on rubbish in a park. For example, an article that began "Residents living around the Atlasville Spruit have been waking up to a stench in the last few weeks" did repeatedly mention pollution in a bird sanctuary (Tshetlo 2014, September 12). Our decision to categorize articles in this way was informed by our larger question around green and brown agendas: we used this category for articles with a central focus on human health, not biodiversity or ecosystems. Usefully, and a point not yet raised in the literature, such media stories likely break down the controversial binary and demonstrate the interrelationships between green and brown agendas to readers.

The second most frequently reported theme was Water and Electricity Provision, notably contrasting with Southern cases examined by Dasgupta et al. (2000). Part of this difference may well relate to sampling techniques and, consequently, is based on different conceptions of what counts as environmental reporting: S1 did not return any articles with this framing; none use the word environment to describe the problem. These articles focused on service provision (or lack thereof) and measurement, primarily in households. Rarely were these controversial, instead typically taking an informative tone, although "Living Africa negates allegations of cutting off Comets water supply" (June 28 2013) presents a conflict between a property company and Comets village. This contrasts with wider reportage on service delivery protests prevalent throughout the country, again indicating a very different framing from national news outlets (Alexander, 2010) and a generally supportive relationship with the local government.

We defined the category 'Nature' quite broadly, including stories about human bodies found in a lake, an overgrown cemetery and a sinkhole. Articles that more closely parallel international environmental discourses arose more frequently in S2; the coding scheme used for $\mathrm{S} 1$ would have identified similar articles if they were present, so their frequency in S2 likely points to a growing inclusion of global discourses in the paper. Articles in this theme were again frequently action-oriented: readers were called upon to participate in a research project on invasive species, and another article shared information about free entrance to the national parks, concluding "SANParks encourages all South Africans and especially teachers and schools to diarise these dates and plan a visit to a national park nearby" (No Author, 2014, Sept 5). Such stories provide a complex notion of 'nature' as a site of recreation, but also a danger and social expense that requires investment and management.

The newspaper also reported on weather related issues, which include significant events and consequences of weather, particularly summer thunderstorms. Articles headlined "Flooding Problems Prove Hazardous" (No Author, 2013, March 1) and "Oh 'Hail No' Storm Wreaks Havoc" (No Author, 2013, November 22) are typical of the climatological region, with its seasonal intense storms. They report the direct impact caused by weather events but do not make connections to causes or broader impacts, similar to the framing of Water and Electricity Provision articles. Such articles reinforce notions of 'nature' as unwieldy and dangerous, as well as the need for financial investment in its management, or at least the management of its impacts. Weather articles also only arose in S1, indicative of the separation of systemic environmental patterns with particular incidents found internationally. One article did focus on climate change: "Time to reflect on our suffering climate" (Englebrecht, 2015, April 8) was written by the editor in first person. This piece repeatedly conflates environmental issues and climate change, and 
provides a rather sweeping commentary prompted by the recent Earth Hour event. The only article in the sample to mention the UN, it also calls for action, for the reader to reflect and "[take] simple action, like recycling". Climate change was also cursorily pointed to as an example of an environmental problem in three additional articles.

Interestingly, environmental concerns with mining and other industries, noted to be key environmental concerns in the municipality (Ekurhuleni Metropolitan Municipality, 2004), were only raised twice. One article directly deals with the question of acid mine drainage, and was prompted by an interaction between politicians over the safety of provincial water and what sphere of government should redress the issues (Engelbrecht, 2014, July 18). Nearly all of the text is a quotation from the opposition party, the Democratic Alliance spokesperson on Environment in Gauteng, likely indicating that the newspaper worked from a press release. The other article is an oblique reference to mining in a wider discussion of environmental rights. This finding correlates with research into local environmental reporting which suggests that local media are unlikely to critique the businesses on which local economies rely (Hansen, 2010; Taylor, 2000). This tendency to avoid critique may be reinforced by the uncomfortable, specific interconnections between the mining industry and historic apartheid economic policy, as well as the disproportionate health impacts of mining environmental legacies for black South Africans (Munnik 2010).

General commentaries were present a surprising number of times particularly in S2. This may represent a growing interest in environmental coverage but a limited capacity for reporting, or an unusual period in the news cycle: articles covered the Miss Earth SA contestants, green awards won by the municipality, and youth education events. In each, the environment is prominent, although in contrast to other coverage, these articles tend not to call for specific actions from the reader. Interestingly, it is often youth (including the contestants) who are presented as actors and sources of change. For example, the Deputy Minister of Water and Environment Affairs said, "This [educational event] gives us hope that when we die, our country and mother earth will be in safe hands" (No Author, 2013, July 5). This framing counters some of the recent negative post-apartheid discourse, and plays into the notion that the 'born frees' (those born after the end of apartheid) may be the source of future positive social change.

In rather stark contrast, a different article includes several photos of a gray-haired white man in camouflage reminiscent of apartheid-era army gear speaking to a rather bewildered and unenthusiastic group of learners (Mthupha, 2014, September 16). A caption unironically notes he is "armed with a PhD", and the associated text unproblematically describes his efforts at 'educating' students about appropriate values and behaviour. In contrast to the activities present the other educational articles, such as walking with students through their environment, this article tells a story of one-way relaying of information. According to the NGO 'educator', "Most of the threats facing our nature arise from inadequate knowledge and understanding among residents about the importance of it, its conservation and the consequences of its destruction". Certainly, there is much in this that resonates with highly problematic, racialized environmental education discourses found in the apartheid era and continuing today (Le Grange, 2004); here, it represents a single article in a wider array of coverage of educational initiatives.

We also noted four broad patterns in the style of writing in the articles. First, the municipal government was framed in two rather distinct, contrasting ways. Many articles emphasized a lack of provisions from local government (e.g. pollution and water and electricity). Others appeared to by copy written as communication by local government (as noted above on acid mine drainage and waste in the drains; see Wakefield and Elliot, 2003). This raises 
important questions about authorship which we discuss further below. Second, the causes and consequences of environmental issues were largely absent, and throughout our sample data and statistics were not presented, largely in keeping with international trends. Third, rarely were opposing sides presented to an issue, in contrast with patterns found in studies of national or international media. Fourth, actors were infrequently given individual voices, although when this was present it tended to follow international trends and include voices of authority, such as the mayor ("Mayor apologises for recent power outages", No Author, 2013, Feb 15), experts ("Spot a parakeet in aid of research study", No Author, 2015) and celebrities such as the Miss Earth SA contestants.

\section{Considering local environmental news reactions}

In this section, we review the findings from our focus groups. Importantly, focus groups can provide insight into respondents' perspectives, and are therefore useful for understanding environmental imaginaries, but are limited as they do not measure actual behaviour. Our focus groups indicated that The Advertiser's readers generally see the local newspaper as resonating with their own values and priorities regarding environmental issues, resembling their position more closely than other news sources. Participants in all focus groups, with the exception of the higher income group, reported that they read local newspapers more frequently than other newspapers although there were a few participants who read nationals newspapers regularly ${ }^{5}$. Despite their frequent use of The Advertiser, participants feel they "get what they pay for" from the free local paper: they suggested the standard of reporting and the presentation of articles is of a lower quality than in national papers, there is limited specialization of reporters, and the advertising distracted from other content. Further, there was some scepticism regarding the relationship between the newspaper and the local government; residents noted that articles sometimes appeared to uncritically reflect government messages and actions. It was noted that national media does have a higher standard of news, a fact which some residents found compelling. However, participants suggested that articles from national news outlets are often dragged out and provide more scientific information than the participants desire and understand. They also note the foreign sourcing of national articles and question their relevance to South Africa (cf Tago, 2010; Sampei and Aoyogi, 2009).

All five of the focus groups agreed that water is the biggest environmental issue affecting the local community in terms of adequate provision, leaking sewage pipes and pollution. The local government was seen to be primarily responsible for this problem; overall, participants had a negative view of the capacity of local government to respond to environmental problems. Although the residents agreed that water was the biggest environmental issue, they also noted that The Advertiser frames such local environmental content as a 'municipal issue' instead of 'environmental.' This was apparent in our own categorization as well; as noted above, water was

\footnotetext{
${ }^{5}$ According to focus group participant self-reports, no participants in Vila Lisa read national news, but all sometimes read local newspapers. Their preferred source of news was TV. In Sunward Park, no participants ever read local news while one read national news regularly; their preferred source was internet and TV. In the Boksburg Central A \& B groups, most participants read local newspapers, and one participant read national newspapers regularly; the generally preferred source was the internet and TV. In Impala Park, one participant read national newspapers regularly and one or two participants read local newspapers occasionally; participants' preferred news source was the internet. This diversity certainly raises important questions about the need to be cautious in generalizing findings regarding newspapers at various scales, including claims about the relationship between newspaper and internet news consumption.
} 
indirectly a topic in many articles and arose less often in S2. We suggest that these points may well be connected: the framing of water issues as a municipal issue may influence and be influenced by local residents belief that local government is responsible for both causing and redressing these concerns. However, the paper's reporting diverges from local residents' environmental imaginaries when framing water-related issues largely in municipal terms and not additionally describing them as environmental issues.

Participants reported some disagreement regarding the need for more environmental information in the local news. While many thought this was important, one group argued that more information was not needed as participants are experiencing and thus have first-hand knowledge about the issues. This argument has similarity to Chapman et al.'s (1997) claim regarding farmers' direct experience of climate change in India. However, while many participants state that climate change is an issue that affects them as there are global implications that impact everyone, there was some misrepresentation of what climate change actually is. This echoes Sampei and Aoyogi's (2009) findings in Japan, in that participants claimed alreadysufficient knowledge but demonstrated a partial and idiosyncratic understanding of the core findings of contemporary climate science.

The participants claimed that residents tend to be more concerned about local issues as they are directly affected by them. One stated, "We basically don't care about Sasol in Sasolburg because we don't get that (type of environmental issue) here, but we get overflowing sewers at the park and in the stream, that's a local issue that concerns us more than anything else." While they do have some consideration for other communities, they only become concerned when they are directly affected by environmental issues. Regarding the debate around fracking in the Karoo region of South Africa, a participant clarifies when they would become concerned: "A person tends to be more focused about what is happening here in our local environment, whereas we know about the fracking but that's the government's problem and Shell's problem, so to speak, because it's not here. When the water from the Karoo gets poisoned and they start cutting our water because they need to give people in the Karoo water then we will become concerned."

Despite this, participants reported that media content in general and The Advertiser in particular, does not directly impact their actions. They suggest that, even at a local level, media lacks insight into local impacts on people and the science behind the effects such as causes of health implications. The result is that residents are reluctant to take action on either small or large-scale issues; they feel they are not impacted or are unable/unaware of how to limit the effect of impacts on their own lives. The participants feel they need more information or more convincing of the consequences of issues being represented by national media outlets, especially if the articles suggest taking actions with financial costs or involving changing cultural values. They believe the media at all scales is not doing enough to link environmental concerns to the average person, including their impacts and appropriate action.

Although the participants generally did not feel that the newspaper reporting impacted themselves and their own actions, they did argue that media coverage may spark more general concern. Many participants indicated that on-going coverage of specific environmental issues may make them seem more important to local residents, and may further incite resident action. There was thus a tension around how participants understood the impact of the media: they claimed to be highly sceptical of the ability of local environmental journalism to make a difference because they blame local government for the problems. At the same time, there was a sense particularly in the low-income focus group that issues are not being addressed by local governments because of limited awareness of both government and the public of their concerns. 
Strikes, in this case, are a means for bringing both government and public attention to the issue, and strikes rely on media to facilitate increased attention. This group noted that impoverished areas are largely excluded from national media and are forced to take drastic actions to garner attention when their concerns are unaddressed. Therefore, although focus group respondents did not see increased awareness as an end in itself, and did not believe that reading newspapers changed their own individual action, they did see reporting as a means of drawing attention to an issue, and that this increased attention was part of a wider project of motivating for government attention.

\section{Conclusion}

Boksburg's specific environment and history surely shapes the reportage of The Advertiser as well as the way residents engage with and understand their environment, contributing to a place-specific environmental imaginary that, as our participants reported, draws on discourses at many scales: 'nature' can be dangerous (where you throw bodies, or the source of storms and floods) or recreational, but both require financial investment and management; apartheid thinking continues to shape educational policies as well as hopes for the future (notable in the youth education programmes); mining and industrial histories and current dependencies shape both the problems (including water pollution), and a seeming reluctance to report on these; and the public frustrations with the limitations of service delivery combined with a close relationship to the state result in a fraught portrayal of local government, its role and its capacities. While the examination of a single newspaper makes this study more suggestive than definitive, several key themes emerge that raise important questions about environmental news coverage. First, our analysis suggests that there may be important differences in both topics and treatment in local environmental news reporting when compared to the predominant research on regional-, national- and international-scale news outlets: (1) a focus on brown themes, and idiosyncratic framings of green issues where present, as well as articles that draw connections between green and brown concerns; (2) attention to hyper-local impacts although with minimal conflict or context; and (3) regular calls for readers' action and involvement. It also shows the need for a more critical consideration of what is included in analyses of environmental reporting, as this significantly shapes the overall findings. These scalar differences are made more urgent by the data from our focus groups, which suggest local news reporting is (1) the primary written news source for many residents, with a difference between high and other income groups; and (2) generally regarded as resonating more closely with the views and values in its environmental coverage than other news outlets.

Of particular normative as well as theoretical importance is the question of the political implications of our findings regarding local environmental knowledge. If local news consumers read about the environment primarily in terms of sewer service failure (and these readers are, as our study suggests, disproportionately poorer and less formally educated), while national news consumers read about it primarily in terms of the conservation of charismatic megafauna and the invisible composition of atmospheric gasses, then this contributes to a diverging interpretation of the environment. Further, if 'brown' issues like sewer failures are not presented as environmental, then readers are likely to view the environment as external and outside, not relevant to their everyday lives. Finally, responsibility is also importantly differently construed: local news consumers are called on to act through their local papers on local environmental problems, yet the wealthy read narratives that leave the reader outside the scope of responsibility, 
occasionally calling for financial donations but not hailing a wider sense of responsibility. Although this may be construed as empowering for local residents in that it presents them as having agency, it may well also reinforce the notion of the poverty-environmental degradation nexus (Moseley and Gray, 2005), implicitly attributing responsibility to the poor for conditions often beyond their control.

This divergent framing, we suggest, contributes to a rift between the environmental imaginations of local and (inter)national media readers that has not been sufficiently examined in scholarship about environmental imaginations. While there are some generalizations about "environmentalisms of the poor", there is a need for more detailed, place-specific explications. This rift also likely has profound impacts on how environmental policy is framed, motivated and received by publics in both global South and North contexts, and requires further scholarly attention.

\section{Disclosure statement}

No potential conflict of interest was reported by the authors.

\section{Funding}

This work was supported by the Urban Studies Foundation.

\section{Acknowledgements}

Mary would like to thank the Urban Studies Foundation for support for this research.

\section{References}

Åkerlund, U., \& Sandberg, L. (2015). Stories of lifestyle mobility: representing self and place in the search for the 'good life'. Social \& Cultural Geography, 16, 351-370.

doi:10.1080/14649365.2014.987806

Alexander, P. (2010). Rebellion of the poor: South Africa's service delivery protests-a preliminary analysis. Review of African Political Economy, 37(123), 25-40. doi:10.1080/03056241003637870

Amu, C., \& Agwu, A. (2012). Attitude and knowledge of print media journalists towards reporting on climate change new in Nigeria. Journal of Agricultural Extension, 16 (2), 52-67.

doi:10.4314/jae.v16i2.5

Baeten, G. (2002). Western utopianism/dystopianism and the political mediocrity of critical urban research. Geografiska Annaler: Series B, Human Geography, 84, 143-152. doi: 10.1111/j.04353684.2002.00120.x

Barchiesi, F. (2010). Informality and casualization as challenges to South Africa's industrial unionism: manufacturing workers in the East Rand/Ekurhuleni region in the 1990s. African Studies Quarterly, 11, 67. Retrieved from http://asq.africa.ufl.edu/files/Barchiesi-Vol11Is2-3.pdf 
Batta, H., Ashong, A., \& Bashir, A. (2013). Press coverage of climate change issues in Nigeria and implications for public participation opportunities. Journal of Sustainable Development 6 (2), 56-69. doi:10.5539/jsd.v6n2p56

Benson, R. (2006). News media as a 'journalistic field': what Bourdieu adds to new institutionalism, and vice versa. Political Communication 23, 187-202. doi:10.1080/10584600600629802

Bessinger, J. (2013). Rooted in reality: readership trends from ROOTS survey. http://themediaonline.co.za/2013/06/rooted-in-reality-readership-trends-from-roots-survey/

Boykoff, M., \& Boykoff, J. (2007). Climate change and journalistic norms: a case study of the US mass-media coverage. Geoforum, 38, 1190-1204. doi:10.1016/j.geoforum.2007.01.008

Braun, B. (2015). Futures: Imagining Socioecological Transformation- An Introduction. Annals of the Association of American Geographers, 105, 239-243. doi:10.1080/00045608.2014.1000893

Brosius, H., \& Kepplinger, H. (1990). The Agenda-setting function of television news. Communication Research, 17, 183-211. doi: 10.1177/009365090017002003

Brossard, D., Shanahan, J., \& McComas, K. (2004). Are issue-cycles culturally constructed? A comparison of French and American coverage of global climate change. Mass Communication and Society, 7, 359-377. doi:10.1207/s15327825mcs0703_6

Campbell, F. (1999). The Construction of environmental news: A study of Scottish journalism. Abingdon: Ashgate.

Castree, N. (2004). Differential geographies: place, indigenous rights and 'local' resources. Political geography, 23, 133-167. doi:10.1016/j.polgeo.2003.09.010

Castree, N., \& Braun, B. (Eds.). (2001). Social nature: Theory, practice, and politics (No. 306.1 S63). Oxford: Blackwell Publishers.

Chapman, G., Kumar, K., Fraser, C., \& Gaber, I. (1997). Environmentalism and the mass media: the north-south divide. London: Routledge.

Corbett, J. (1998). The environment as theme and package on a local television newscast. Science Communication, 19, 222-37. doi: 10.1177/1075547098019003004

Cox, R. (2013). Environmental communication and the public sphere. London: Sage.

Crawley, C. (2007). Localized debates of agricultural biotechnology in community newspapers- a quantitative content analysis of media frames and sources. Science Communication, 28, 314-346. doi: $10.1177 / 1075547006298253$

Dasgupta, S., Laplante, B., \& Meisner, G. (2000). Environmental news in Argentina, Chile, Mexico and the Philippines. Local Environment: International Journal of Justice and Sustainability, 5, 351359. 
Derickson, K. D., \& MacKinnon, D. (2015). Toward an interim politics of resourcefulness for the Anthropocene. Annals of the Association of American Geographers, 105, 304-312.

doi:10.1080/00045608.2014.1001002

Edensor, T. (2015). The gloomy city: Rethinking the relationship between light and dark. Urban Studies, 52, 422-438. doi: 10.1177/0042098013504009

Ekurhuleni Metropolitan Municipality (2004). State of the Environment Report 2004 Summary. Johannesburg: Ekurhuleni Metropolitan Municipality.

Elwood, S., Lawson, V., \& Nowak, S. (2015). Middle-class poverty politics: Making place, making people. Annals of the Association of American Geographers, 105(1), 123-143.

doi:10.1080/00045608.2014.968945

Escobar, A. (2001). Culture sits in places: reflections on globalism and subaltern strategies of localization. Political geography, 20,139-174. doi:10.1016/S0962-6298(00)00064-0

Freund, B. (2001). Brown and green in Durban: the evolution of environmental policy in a postapartheid city. International Journal of Urban and Regional Research, 25, 717-739. doi: $10.1111 / 1468-2427.00341$

Funkhouse, R. (1973). The Issues of the sixties: an exploratory study in the dynamics of public opinion. The Public Opinion Quarterly, 37 (1), 62-75. doi: 10.1086/268060

Gandy, M. (2015). From urban ecology to ecological urbanism: an ambiguous trajectory. Area, 47, 150-154. doi:10.1111/area.12162

Gans, H. (2004). Deciding what's news: a study of CBS evening news, NBC nightly news, Newsweek, and Time. Evanston: Northwestern University Press.

Gervais-Lambony, P. (2008). Space matters: identity, justice and democracy at the ward level in South African cities. Transformation: Critical Perspectives on Southern Africa, 66(1), 83-97. doi: 10.1353/trn.0.0009

Gess, H. (2012). Climate change and the possibility of 'slow journalism'. Ecquid Novi: African Journalism Studies, 33 (1), 54-65. doi:10.1080/02560054.2011.636828

Ginn, F. (2015). When Horses Won't Eat: Apocalypse and the Anthropocene. Annals of the Association of American Geographers, 105, 351-359. doi:10.1080/00045608.2014.988100

Gray, L. C., \& Moseley, W. G. (2005). A geographical perspective on poverty-environment interactions. The Geographical Journal, 171(1), 9-23. doi: 10.1111/j.1475-4959.2005.00146.x Guedes, O. (2000). Environmental issues in the Brazilian press. International Communication Gazette, 62, 537-554. doi: 10.1177/0016549200062006006

Hagerman, C. (2007). Shaping neighborhoods and nature: Urban political ecologies of urban waterfront transformations in Portland, Oregon. Cities, 24, 285-297. doi:10.1016/j.cities.2006.12.003 
Hansen, A. (1991). The media and social construction of the environment. Media, Culture and Society, 13, 443-458. doi: 10.1177/016344391013004002

Hansen, A. (2010). Environment, Media and Communication. Routledge: London.

Herman, E., \& Chomsky, N. (1998). Manufacturing consent: the political economy of the mass media. Pantheon Press: New York.

Huber, M. T., \& Currie, T. M. (2007). The urbanization of an idea: imagining nature through urban growth boundary policy in Portland, Oregon. Urban Geography, 28, 705-731. doi:10.2747/02723638.28.8.705

Huber, M., \& Currie, T. (2007). The urbanization of an idea: imagining nature through urban growth boundary policy in Portland, Oregon. Urban Geography, 28, 705-731. doi: 10.2747/02723638.28.8.705

Jones, N. (2012). 'Sexing up' environmental issues: exploring media eco-ethics, advocacy and journalism in a South African context. Ecquid Novi: African Journalism Studies, 33 (1), 26-43. doi:10.1080/02560054.2011.636826

Kallis, G., \& March, H. (2015). Imaginaries of Hope: The Utopianism of Degrowth. Annals of the Association of American Geographers, 105, 360-368. doi:10.1080/00045608.2014.973803

Kitson, J., \& McHugh, K. (2015). Historic enchantments-materializing nostalgia. Cultural Geographies, 22, 487-508. doi:10.1177/1474474014549946

Lawhon, M. (2013). Situated, Networked Environmentalisms: A Case for Environmental Theory from the South. Geography Compass, 7, 128-138. doi: 10.1111/gec3.12027

Lawhon, M. \& Makina, A. (In press). Assessing local discourses on water in a South African newspaper. Local Environment.

Lawhon, M., \& Fincham, R. (2006). Environmental issues in the Southern African media: A case study of the Natal Witness. Southern African Journal of Environmental Education, 23, 107-120. Retrieved from: http://www.eeasa.org.za/images/publications/eeasa_journal_23_2006/eeasa_2006_27_02_07_final_ web.pdf

Le Grange, L. (2004). Embodiment, social praxis and environmental education: Some thoughts. Environmental Education Research, 10(3), 387-399. http://doi.org/10.1080/1350462042000258206

Lester, E. (2010). Media and Environment: Conflict, Politics and the News. Polity Press: Cambridge.

Lewis, T. (2000). Media representations of "sustainable development": sustaining the status quo? Science Communication, 21, 244-273. doi: 10.1177/1075547000021003003

Lipset, D. (2014). Place in the Anthropocene: A mangrove lagoon in Papua New Guinea in the time of rising sea-levels. HAU: Journal of Ethnographic Theory, 4, 215-243. doi: 10.14318/hau4.3.014 
Martinez-Alier, J. (2003). The Environmentalism of the poor: a study of ecological conflicts and valuation. Cheltenham: Edward Elgar Publishing.

Martinez-Alier, J. (2014). The environmentalism of the poor. Geoforum, 54, 239-241.

doi:10.1016/j.geoforum.2013.04.019

McCauley, S. M., \& Murphy, J. T. (2013). Smart growth and the scalar politics of land management in the Greater Boston region, USA. Environment and Planning A, 45, 2852-2867. doi:

$10.1068 / \mathrm{a} 45307$

McGranahan, G., \& Satterthwaite, D. (2000). Environmental health or ecological sustainability: reconciling the brown and green agendas in urban development. In Pugh, C. (ed.), Sustainable Cities in Developing Countries (pp. 73-90). Earthscan: London.

McGregor, A. (2004). Sustainable development and 'warm fuzzy feelings': discourse and nature within Australian environmental imaginaries. Geoform, 35, 593-606.

doi:10.1016/j.geoforum.2004.02.001

Mels, T. (2009). Analysing Environmental Discourses and Representations. In N. Castree, D. Demeritt, D. Liverman, \& B. Rhoads (Eds.), A companion to environmental geography (Pp. 385-99). Chichester: John Wiley \& Sons.

Millington, N. (2013). Post-industrial imaginaries: Nature, representation and ruin in Detroit, Michigan. International Journal of Urban and Regional Research, 37(1), 279-296. doi: 10.1111/j.1468-2427.2012.01206.x

Molotch, H., \& Lester, M. (1974). News as purposive behaviour. American Sociological Review, 39 (1), 101-112. Retrieved from: http://citeseerx.ist.psu.edu/viewdoc/download?doi=10.1.1.468.6036\&rep=rep1\&type=pdf

Munnik, V. (2010). The Social and Environmental Consequences of Coal Mining in South Africa: A Case Study. White paper by the Environmental Monitoring Group, Cape Town, South Africa and Both ENDs, Amsterdam, The Netherlands. Retrieved from http://www.bothends.org/uploaded_files/uploadlibraryitem/1case_study_South_Africa_updated.pdf

NAB. (2013). Roots Overview. Retrieved from http://www.nab.co.za/roots-overview/

Parnell, S., and Pieterse, E. (2002). Developmental Local Government, in S. Parnell, E. Pieterse, M. Swilling, and D. Woolridge, eds., Democratising Local Government: the South African Experiment, UCT Press: Cape Town.

Pierce, J., \& Martin, D. G. (2015). Placing Lefebvre. Antipode, 47, 1279-1299. doi: 10.1111/anti.12155

Pierce, J., Martin, D., \& Murphy, J. (2011). Relational place-making: the networked politics of place. Transactions of the Institute of British Geographers, 36, 54-70. doi: 10.1111/j.14755661.2010.00411.x 
Pierce, J. \& Lawhon, M. (2015). Walking as method: toward methodological forthrightness and comparability in urban geographical research. The Professional Geographer 67, 655-662.

Priest, S., \& Ten Eyck, T. (2004). Transborder information, local resistance, and the spiral of silence: biotechnology and public opinion in the United States. In Braman, S. (Ed.), Biotechnology and Communication: The Meta-Technologies of Information (pp. 175-196). New Jersey: Lawrence Erlbaum Associates.

Rao, S. (2012). The case for "green pen journalism" in an age of globalisation and liberalisation. Ecquid Novi: African Journalism Studies, 33 (1), 3-14. doi:10.1080/02560054.2011.636829

Rios, M., \& Watkins, J. (2015). Beyond "Place" Translocal Placemaking of the Hmong Diaspora. Journal of Planning Education and Research, 35, 209-219. doi:

$10.1177 / 0739456 \times 14568023$

Roots Survey. Retrieved from The Media Online: http://themediaonline.co.za/2013/06/rooted-inreality-readership-trends-from-roots-survey/

Sampei, Y., \& Aoyagi-Usui, M. (2009). Mass-media coverage, its influence on public awareness of climate-change issues, and implications for Japan's national campaign to reduce greenhouse gas emissions. Global Environmental Change, 19, 203-213. doi:10.1016/j.gloenvcha.2008.10.005

Shanahan, J., Morgan, M., \& Stenbjerre, M. (1997). Green or brown? Television and the cultivation of environmental concern. Journal of Broadcasting and Electronic Media, 41, 305-323. doi:10.1080/08838159709364410

Soloski, J. (1989). Sources and channels of local news. Journalism Quarterly, 66, 864-870. doi: $10.1177 / 107769908906600413$

Strauss, K. (2015). These overheating worlds. Annals of the Association of American Geographers, 105, 342-350. doi:10.1080/00045608.2014.973805

Tagbo, E. (2010). Media coverage of climate change in Africa: a case study of Nigeria and South Africa (Reuters Institute Fellowship Paper, Reuters Institute for the Study of Journalism) Oxford: University of Oxford. Retrieved from http://reutersinstitute.politics.ox.ac.uk/publication/media-coverage-climate-change-africa

Taylor, C. E., Lee, J. S., \& Davie, W. R. (2000). Local press coverage of environmental conflict. Journalism \& Mass Communication Quarterly, 77, 175-192. doi: 10.1177/1748048510386739

Todes, A., Karam, A., Klug, N., \& Malaza, N. (2010). Beyond master planning? New approaches to spatial planning in Ekurhuleni, South Africa. Habitat International, 34, 414-420.

doi:10.1016/j.habitatint.2009.11.012

Vormann, B. (2015). Toward an infrastructural critique of urban change: Obsolescence and changing perceptions of New York City's waterfront. City,19, 356-364. doi:10.1080/13604813.2015.1018062

Wakefield, S., \& Elliott, S. (2003). Constructing the news: the role of local newspapers in 
environmental risk communication. The Professional Geographer, 55, 216-226. doi:10.1111/00330124.5502009

\section{The Boksburg Advertiser}

Engelbrecht, R. (2014, July 18). MEC washes hands of Acid Mine Drainage issue - DA. The Boksburg Advertiser. Retrieved from http://boksburgadvertiser.co.za/203842/gauteng-environmentmec-washes-hands-of-acid-mine-drainage-issue/

Engelbrecht, R. (2015, April 8). Time to reflect on our suffering climate. The Boksburg Advertiser. Retrieved from http://boksburgadvertiser.co.za/227266/time-for-all-to-reflect-on-our-sufferingclimate/

Mthupha, F. (2014, September 16). Iswi Lethu deals with conservation in the classroom. The Boksburg Advertiser. Retrieved from http://boksburgadvertiser.co.za/209246/izwi-lethu-takesconservation-into-the-classroom/

Tshetlo, T. (2014, September 12). Contamination in the Atlasville Spruit. The Boksburg Advertiser. Retrieved from http://boksburgadvertiser.co.za/208554/contamination-in-the-atlasville-spruit/ No Author. (2013, January 25). Doom's lake mysteries, investigations continue into discovery of three bodies. The Boksburg Advertiser, p.1.

No Author. (2013, March 1). Flooding problems prove hazardous. The Boksburg Advertiser, p. 19. No author (2013, July 5). Youth water summit held in Boksburg. The Boksburg Advertiser. Retrieved from http://boksburgadvertiser.co.za/11959/youth-water-summit-held-in-boksburg/

No Author. (2013, June 28). Living Africa negates allegations of cutting off Comets water supply. The Boksburg Advertiser, p.12.

No author. (2014, September 5). Enjoy free access to all SANParks. The Boskburg Advertiser. Retrieved from http://boksburgadvertiser.co.za/208677/enjoy-free-access-sanparks/

No Author. (2013, November 12). Oh 'Hail No' Storm Wreaks Havoc. The Boksburg Advertiser, p. 3. 